\title{
"The impact of the COVID-19 pandemic on the due payments of Polish entreprises from selected industries"
}

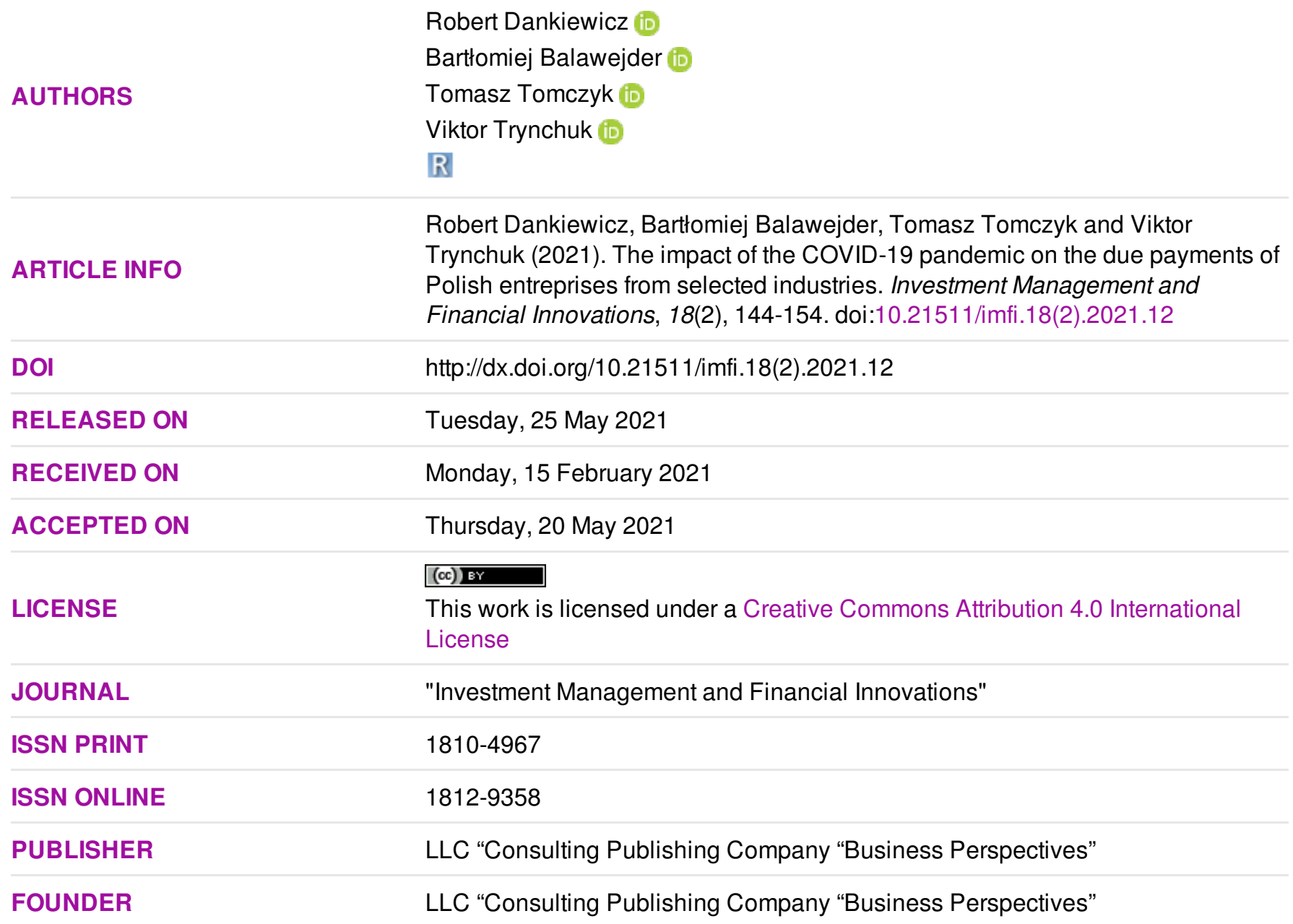

NUMBER OF REFERENCES

48

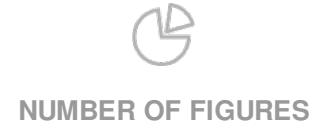

2

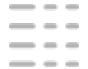

NUMBER OF TABLES

3

C The author(s) 2021. This publication is an open access article. 


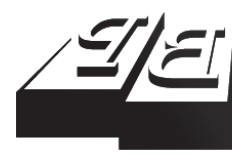

\section{BUSINESS PERSPECTIVES}

(O)

LLC "CPC "Business Perspectives" Hryhorii Skovoroda lane, 10, Sumy, 40022, Ukraine www.businessperspectives.org
Received on: $15^{\text {th }}$ of February, 2021

Accepted on: $20^{\text {th }}$ of May. 2021

Published on: $25^{\text {th }}$ of May, 202

(c) Robert Dankiewicz, Bartłomiej Balawejder, Tomasz Tomczyk, Viktor Trynchuk, 2021

Robert Dankiewicz, Ph.D., Assistant Professor, Department of Finance, Banking and Accounting, Rzeszow University of Technology, Poland. (Corresponding Author)

Bartłomiej Balawejder, Bachelo’s Degree, Insurance Expert, Podkarpacki Dom Ubezpieczeń Sp. z o.o., Poland.

Tomasz Tomczyk, Master's Degree, Assistant, Department of Finance, Banking and Accounting, Rzeszow University of Technology, Poland

Viktor Trynchuk, Ph.D., Assistant Professor, Vice-rector University of the State Fiscal Service of Ukraine, Ukraine.
Robert Dankiewicz (Poland), Bartłomiej Balawejder (Poland),

Tomasz Tomczyk (Poland), Viktor Trynchuk (Ukraine)

\begin{abstract}
The emergence of the COVID-19 pandemic has undoubtedly caused many perturbations, at the same time hindering the functioning and operation of enterprises from various industries, which, due to the often inability to conduct business, found themselves in a very difficult financial situation, with a difficult ability to settle their liabilities. Too high share of receivables that are not settled in a timely manner can result in various problems for enterprises, including, in particular, financial problems that can lead to large-scale bankruptcy. Considering a huge number of connections between individual entities, the bankruptcy of one may pose a risk of a wave of bankruptcy of others. The paper aims to analyze the impact of the COVID-19 pandemic on the payment situation of Polish enterprises. The research was conducted on the basis of an analysis of data on the payment situation of Polish enterprises from selected industries. Basic descriptive statistics was used in the study to characterize the material. The nonparametric Wilcoxon pair order test, which is the equivalent of the Student's t-test for related variables, was used for the research. The research proved that at enterprises from almost every industry, the value of debts at the end of the second quarter of 2020 was higher than in the first quarter. It can therefore be concluded that the outbreak of the pandemic contributed to an increase in arrears, which, in turn, resulted in an increased risk of doing business. The greater the share of arrears with contractors, the greater the risk of financial problems at the enterprise, and hence the increased risk of bankruptcy.
\end{abstract}

Keywords

trade credit, due payments, risk management, financial problems, bankruptcy risk

JEL Classification G32, G33, L53

\section{INTRODUCTION}

The outbreak of the COVID-19 pandemic has caused a severe shock in global markets. Reevaluations and changes in the way we do business are derived from it. The vast majority of enterprises had to learn to perform in a new, much more difficult reality. The restrictions imposed by the governments of individual countries, related not only to movement, but also to limiting the possibility of conducting business, put some entities in a very difficult situation. The exact effects of such restrictions will only be possible from the perspective of a longer period of time. However, there are already some symptoms that indicate a gradually deteriorating financial situation of enterprises operating in various sectors of the economy.

In the realities of the modern world, a very large part of enterprises operate based on a trade credit, which is a possibility of a certain postponement of payments for previously purchased goods or services. On the other hand, there is a certain risk that the counterparty will not 
be able to pay off the liability on time, which, in turn, will have a negative impact on the activities of the entity that granted such a loan. This, in the event of an escalation of the phenomenon, can lead to payment gridlocks, which may adversely affect not only the enterprises themselves, but also the entire economy. The aforementioned risk may appear especially in times of crisis, when the functioning of most enterprises is difficult and their financial state deteriorates significantly. The crisis situation can undoubtedly be talked about in relation to the COVID-19 pandemic, which has become a factor that significantly worsened the financial situation of many entities.

Based on the sample of entities operating in various sectors of the economy, it was indicated how the backlog of Polish enterprises changed in the first months of the pandemic. An attempt was also made to indicate the possible potential consequences of the phenomenon.

\section{LITERATURE REVIEW}

Contemporary market realities make enterprises operate based on a trade credit. Such a model of functioning is based on a deferral of payments for goods or services. The scale of using a trade credit in running a business is very large, which is why it is often indicated that a trade credit is the largest source of financing enterprises' activities in the short term (Petersen \& Rajan, 1997), and it is also a key element of their liabilities. One can find many arguments that support the use of the abovementioned solution, and in some way justify its huge popularity. The popularity of the trade credit may be evidenced by the fact that in Western Europe the percentage of corporate purchases made with the use of credit ranges from $25.4 \%$ to even $56.2 \%$ of the total sales value (ATRADIUS, 2018). As for the countries of Eastern Europe, the percentage of purchases made in this form fluctuates around $67.2 \%$ of total sales, while in Poland it was $48.5 \%$ (ATRADIUS, 2019). At the same time, it should be noted that $54 \%$ of the companies surveyed experienced the impact of late payment of goods and services on their cash flow, and this was one of the worst results in Europe (for instance, for German, Dutch and Hungarian companies, this indicator was $22 \%, 23 \%$ and $23 \%$, respectively) (Lisowski, 2010). However, when analyzing the literature on the subject, one can find four basic motives to use a trade credit in practice (Lisowski \& Chojan, 2020). These are a financial motive, an element of a competitive strategy, reduction of transaction costs, and quality control and signaling (Ciżkowicz-Pękała, 2017).

The positioning of the company as a beneficial business partner seems to be particularly important in times of very strong competition. Such a task can also be attributed to extending the payment term by means of a trade credit. The willingness to compete is one of the main determinants of the company's decision to grant a loan. This is relevant in countries where the banking system is relatively underdeveloped, and companies must constantly strive to maintain a favorable position in the market (Horen, 2004, Khovrak \& Petchenko, 2015, Osieczko, 2019, Pasternak-Malicka, 2019). For this reason, many enterprises decide to allow their contractors to make purchases with deferred payment terms (Baranovsky et al., 2020; Tkachenko et al., 2020). It is also important due to the fact that trade credit allows mitigating price competition in the market (Peura et al., 2017). Referring to the use of a trade credit as a tool supporting a competitive strategy, it is worth mentioning that research shows that the supplier responsible for the majority of purchases is willing to finance more of their sales to a given retailer with trade credit (Chod et al., 2019), which shows that credit merchant can also be, in a sense, a loyalty program for the company's contractors.

Offering contractors, the possibility of financing with a trade credit, apart from having a significant impact on the competitive policy, also translates into the financial results of the entity. Some studies show that a trade credit (granted and received) is directly correlated with the size of an enterprise, and with return on capital, while negatively correlating with return on assets (Bărbuţă-Mişu, 2019). The literature also indicates that a trade credit may have a positive impact on the sustainable development of an enterprise (Huang et al., 2019; Glonti et al., 2020), on innovative activity of an enterprise (Khovrak, 2013), as well as increase the efficiency 
of business operations and help reduce financial constraints (Agostino \& Trivieri, 2019). However, offering a trade credit requires skillful management of receivables in the enterprise (Zimon et al., 2019). It turns out that it can be a profitable solution, because according to some studies, proper receivables management can stimulate and improve cash flow (Kumaraswamy \& George, 2019). From this point of view, insurance through the possibility of providing resources, risk management and resource allocation can be an extremely important element supporting development (Eyskawa \& Janowicz-Lomott, 2014; Levina et al., 2015; Ostrowska-Dankiewicz \& Simionescu, 2020).

It should be remembered that the use of a trade credit in the activities of enterprises is influenced by many exogenous and endogenous factors (Yazdinejad \& Jokar, 2019), while the impact of the trade credit itself on the financial situation of an enterprise and its profitability can affect to varying degrees, depending on its location, reputation, business specificity or market position (Grau \& Reig, 2018).

Despite many benefits for enterprises, it should be borne in mind that the trade credit has some drawbacks and is not an ideal solution. This concern, in particular, a situation where the borrower ceases to settle the obligations towards the entity that granted them the trade credit. Therefore, it seems important to properly manage the trade credit and receivables in order to minimize the effects of late payments on the financial situation of the enterprise, as they are a key obstacle to the development and survival of enterprises (Otto, 2018). The risk management process is closely related to the available information, strategy, and organization of the process, as well as the qualifications of managers (Sołtysiak, 2014). Accordingly, the effectiveness of management decisions and actions depends on both the factors influencing the formation of risk and the sources of risk (Kaigorodova et al., 2018). Obviously, raising awareness and quality of procedure formalization in the entrepreneurs' activities can lead to improved risk management. But it is quite another matter that, despite the existence of certain procedures and/or the functioning of the risk management department, not all types of risk are managed by companies. In particular, some
SMEs have risk management practices based on the preferences of owners and managers, rather than the results of the assessment of existing risks. Accordingly, owners often ignore existing procedures for identifying and managing risks (Dankiewicz et al., 2020).

The literature indicates that working capital management is key when it comes to the results of the activity conducted. Working capital management basically takes place in four areas: creditors, shares, trade debtors and cash (Paul \& Boden, 2011). Trade debtors are pointed out to play a huge role in the cash conversion cycle, and poor working capital management and arrears problems are the main reasons for small business failures (Wilson, 2008). Research shows that late payments limit the growth potential of small enterprises, forcing them not only to reduce employment, but also to limit investments (Białowolski, 2011). The analysis of the literature shows the existence of a dependence indicating that the longer enterprises wait for overdue payments, the lower the level of their investments (Hopkins et. al., 2017). Moreover, it should be mentioned that some studies show that, as a result of late payments, some small enterprises may be forced to increase their debt by extending overdrafts, which in turn may have a negative impact on their survival in the market (Connell, 2014). The negative aspects of using trade credit in the activities of such enterprises may constitute a real risk of payment gridlocks in the economy, and at the same time a real threat of a wave of bankruptcies of enterprises that are unable to effectively enforce receivables from their contractors (Pyrkova et al., 2018). Modern conditions force companies to operate in an extremely dynamic, complex, and unpredictable environment characterized by constant changes. That is why companies must identify a list of the most influential risks that require constant monitoring of the economic and financial situation, as well as forecasting the threat of bankruptcy. This will allow the company to develop and implement risk response mechanisms in a timely manner (Dankiewicz, 2020).

The possible negative consequences of using a trade credit have been strongly exacerbated by the COVID-19 pandemic. This pandemic will 
trigger what can be safely referred to as a crisis. In retrospect, some effects that the pandemic has had on companies can already be seen (Polinkevych et al., 2021). The closure of individual areas of the economy made it necessary to reevaluate certain issues, especially those related to the business model. Part of the activities of enterprises had to be moved to the virtual space, and it is increasingly indicated that some enterprises may remain in this space (Ritter \& Pedersen, 2020).

The emergence of the COVID-19 pandemic has undoubtedly had a heavy impact on the entire economy and its individual components. However, it can be seen that the pandemic has not affected all industries equally. While some companies have ceased to exist due to the need to significantly reduce their activities, others, especially those that have found it easier to adapt to the new reality, are recording unprecedented increases (Donthu \& Gustafsson, 2020). It can be seen that the restrictions introduced by the government resulted in a significant decrease in the possibility of shopping in brick-and-mortar premises, which, combined with some concern for health, was an incentive to shift activities to alternative electronic channels (Pantano et al., 2020), which are slowly starting to become a habit of customers (Bhatti et al., 2020). At the same time, the behavior of companies and consumers depends on the level of financial literacy and entrepreneurial skills that can be formed by modern universities (Khovrak, 2019; Trunina et al., 2020).

The powerful effects of the pandemic on the activities of enterprises allow using a crisis definition in the context of the current situation. Limiting the possibility of running a business and, consequently, the inability to earn a living, had a negative impact on the ability of enterprises to settle their liabilities. In such situations, the legitimacy of using a trade credit to finance a business may be questioned. The literature indicates that in difficult times some enterprises perform better than others (Lee et al., 2017). Most often, small and medium-sized enterprises are the victims of crises (Jurgilewicz et al., 2020), which in a sense, have to bear a lot of responsibility for their small size (Eggers, 2020), and any, even small payment gridlocks can lead to their bankruptcy (Zimon, 2020). However, research shows that the use of trade credit had a significant and very positive impact on the survival of small and medium-sized enterprises in the financial crisis, especially those with certain financial constraints (McGuinness et al., 2018).

\section{AIMS}

The paper aims to analyze the impact of the COVID-19 pandemic on the payment situation of Polish enterprises. Timely payment of liabilities is extremely important from the point of view of the stability of the functioning of enterprises in a given sector, as well as the entire economy in the country. Therefore, based on a group of entities operating in various sectors of the economy, it was indicated how the status of arrears in payments of Polish enterprises changed in the first months of the pandemic. Considering how important it is for contractors to settle their liabilities in a timely manner, an attempt was also made to indicate possible potential consequences of this phenomenon for the future functioning of individual sectors, as well as the entire economy.

\section{METHODOLOGY}

The research was carried out on the basis of an analysis of the data available in the market regarding the payment situation of Polish enterprises operating in selected key sectors of the economy. The data used in the study came mainly from the Credit Information Bureau and the Central Statistical Office databases. They were processed using descriptive statistics in order to describe the phenomenon being the subject of the work. The studies deliberately juxtaposed different industries to see which of them were most affected by the COVID-19 pandemic in terms of the payment situation. The research was carried out for two periods of time. The first period, until the first quarter of 2020, is the period when the pandemic just started in Poland and therefore did not yet significantly affected the economy. The second period was the second quarter of 2020 , i.e., the time when a 
dynamic increase in the number of COVID-19 patients was observed, and there was a closure of individual areas of the economy. Preventing enterprises from operating by introducing new restrictions had to have a significant impact on their financial situation and on their ability to settle their obligations, in particular those related to the necessity to pay for goods and services, for which the payment deadline was postponed to various degrees. The comparison of these two periods allowed showing a preliminary picture of the impact of the pandemic on the state of arrears at Polish enterprises.

In the study, basic descriptive statistics was used to characterize the material. The research used the non-parametric Wilcoxon's pairwise order test, which is an equivalent of the Student's t-test for related variables. The use of the above-mentioned test allows checking whether there was a significant difference in the variables studied before and after the introduction of a given factor, which in the conducted research is the occurrence of the COVID-19 virus, and its limitations. The null hypothesis (H0) says that no changes took place.

\section{RESULTS}

\subsection{Value of due payments}

The research was conducted for two periods at the end of the first and the second quarter of 2020 .

Trade, industry and construction are the three sectors with the highest values of due payments. Figure 1 shows that in these sectors there was an increase in due payments in the periods analyzed. Three sectors have the lowest values of due payments: production and supply of energy, gas and hot water, culture, entertainment and recreation, and education.

The Wilkoxon pair order test checked whether there was a significant difference in the value of due payments in the first and in the second quarter of 2020. The research shows that these differences are significant, $p<\alpha(p=0.0214)$. The largest increase was in trade ( 0.23 billion). In the industrial, transport and construction sectors, there has also been an in-crease ranging from 0.1 to 0.14 billion. Of note are three industries in which due payments declined: real estate services, mining and quarrying, and professional and scientific activities.

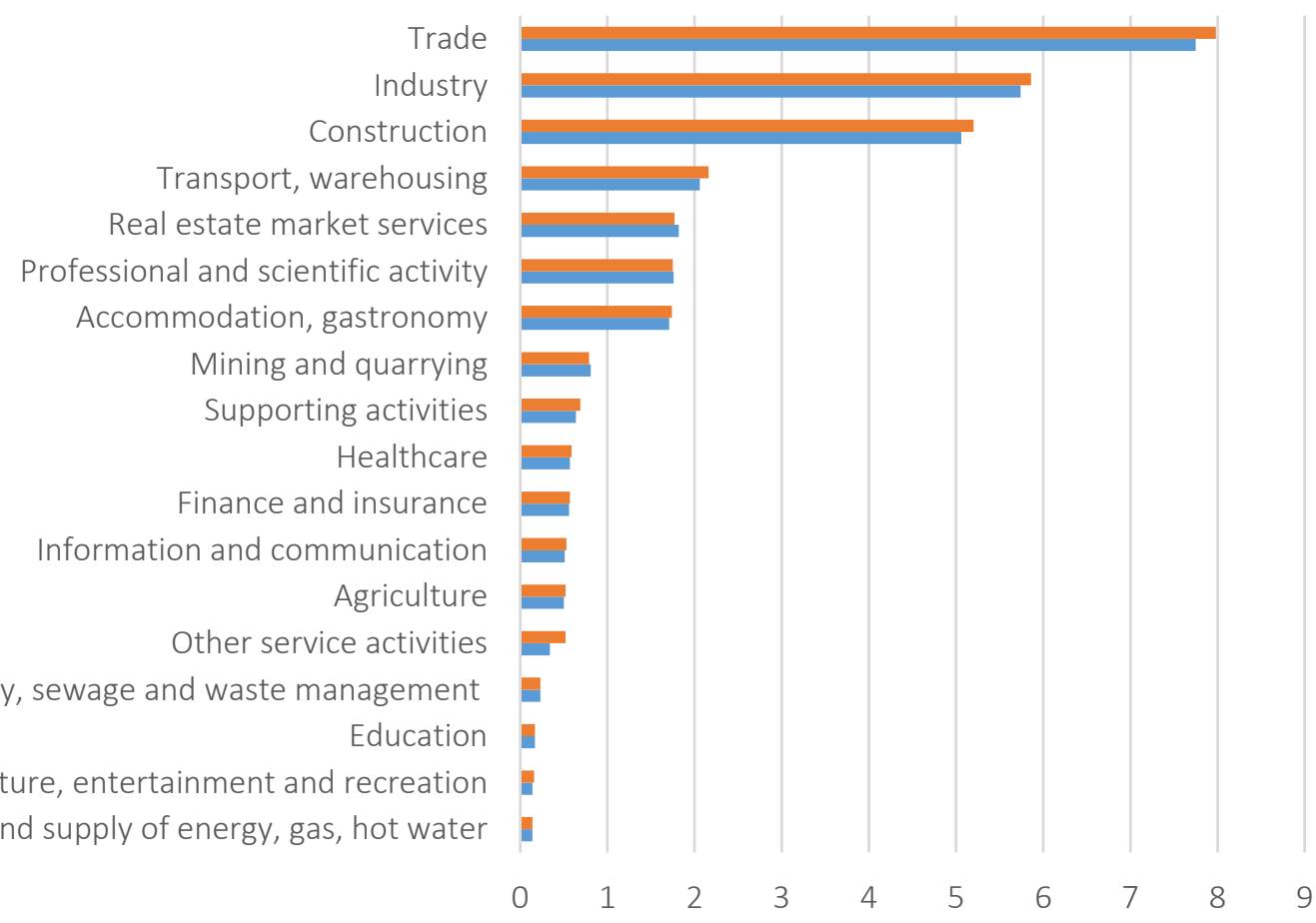

Note: $\mathrm{Q}$ - quarter.

Due payments at the end of Q2

Due payments at the end of Q1

Figure 1. Due payments at the end of Q1 and Q2 by industry 
Table 1. Value of due payments at the end of the month (in PLN billion)

\begin{tabular}{|c|c|c|c|}
\hline Sector & End of Q1* & End of Q2 & Change \\
\hline Generation and supply of energy, gas, hot water & 0.14 & 0.16 & 0.02 \\
\hline Culture, entertainment and recreation & 0.14 & 0.14 & 0 \\
\hline Education & 0.17 & 0.17 & 0 \\
\hline Water supply, sewage and waste management & 0.23 & 0.23 & 0 \\
\hline Other service activities & 0.34 & 0.36 & 0.02 \\
\hline Agriculture & 0.50 & 0.52 & 0.02 \\
\hline Information and communication & 0.51 & 0.53 & 0.02 \\
\hline Finance and insurance & 0.56 & 0.57 & 0.01 \\
\hline Healthcare & 0.57 & 0.59 & 0.02 \\
\hline Supporting activities & 0.64 & 0.69 & 0.05 \\
\hline Mining and quarrying & 0.81 & 0.79 & -0.02 \\
\hline Accommodation, gastronomy & 1.71 & 1.74 & 0.03 \\
\hline Professional and scientific activity & 1.76 & 1.75 & -0.01 \\
\hline Real estate market services & 1.82 & 1.77 & -0.05 \\
\hline Transport, warehousing & 2.06 & 2.16 & 0.1 \\
\hline Construction & 5.06 & 5.20 & 0.14 \\
\hline Industry & 5.74 & 5.86 & 0.12 \\
\hline Trade & 7.75 & 7.98 & 0.23 \\
\hline
\end{tabular}

Note: $* \mathrm{Q}$-quarter.

\subsection{Share of companies with problems in a given sector}

The largest number of companies experiencing problems are those most often operating in the transport and storage industry, in the industry of water suppliers, sewage and waste management, as well as those operating in the mining and quarrying industry.

Transport, warehousing

Water supply, sewage and waste management

Mining and quarrying

Professional and scientific activity

Trade

Construction

Generation and supply of energy, gas, hot water Industry

Finance and insurance

Supporting activities

Real estate market services

Agriculture

Culture, entertainment and recreation

Information and communication

Accommodation, gastronomy

Other service activities

Education

Healthcare
The smallest share of companies with problems is in healthcare, education and other service activities (Figure 2).

The Wilkoxon pair order test checked whether there was a significant difference in the share of companies with problems in the first and in the second quarter of 2020. The research shows that the differences are not statistically significant,

0,0\% 1,0\% 2,0\% 3,0\% 4,0\% 5,0\% 6,0\% 7,0\% 8,0\% 9,0\%10,0\%

- Share of companies with problems at the end of Q2

- Share of companies with problems at the end of Q1

Note: $\mathrm{Q}$ - quarter.

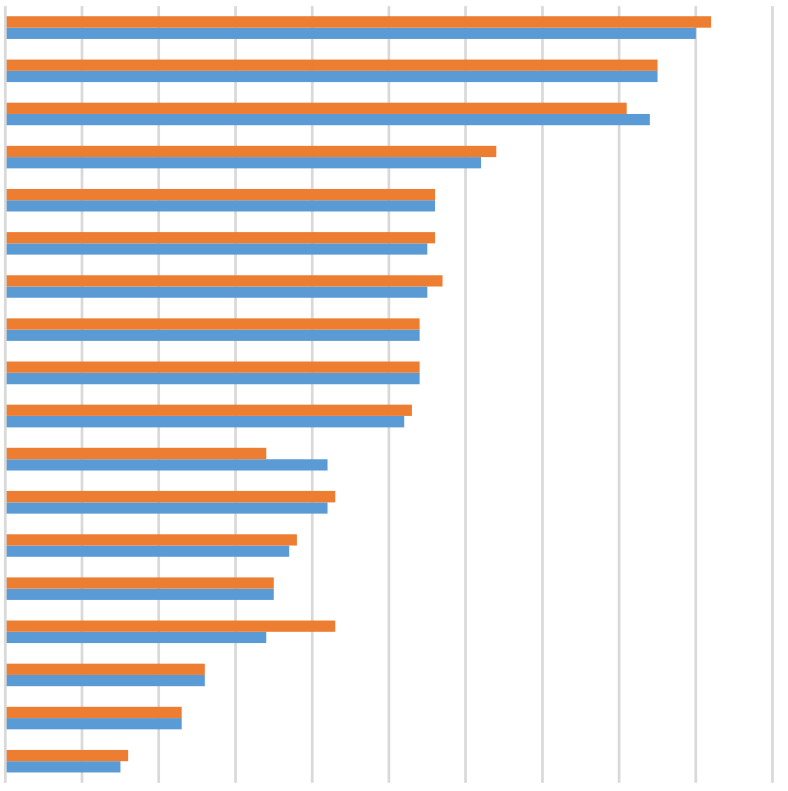


Table 2. Share of companies with problems in a given sector at the end of Q1 and Q2*

\begin{tabular}{|c|c|c|c|}
\hline Sector & $\begin{array}{c}\text { Share of companies with } \\
\text { problems at the end of } \\
\text { Q1 }\end{array}$ & $\begin{array}{c}\text { Share of companies with } \\
\text { problems at the end of } \\
\text { Q2 }\end{array}$ & Change \\
\hline Healthcare & $1.5 \%$ & $1.6 \%$ & $0.1 \%$ \\
\hline Education & $2.3 \%$ & $2.3 \%$ & $0.0 \%$ \\
\hline Other service activities & $2.6 \%$ & $2.6 \%$ & $0.0 \%$ \\
\hline Accommodation, gastronomy & $3.4 \%$ & $4.3 \%$ & $0.9 \%$ \\
\hline Information and communication & $3.5 \%$ & $3.5 \%$ & $0.0 \%$ \\
\hline Generation and supply of energy, gas, hot water & $3.7 \%$ & $3.8 \%$ & $0.1 \%$ \\
\hline Real estate market services & $4.2 \%$ & $3.4 \%$ & $-0.8 \%$ \\
\hline Agriculture & $4.2 \%$ & $4.3 \%$ & $0.1 \%$ \\
\hline Supporting activities & $5.2 \%$ & $5.3 \%$ & $0.1 \%$ \\
\hline Industry & $5.4 \%$ & $5.4 \%$ & $0.0 \%$ \\
\hline Finance and insurance & $5.4 \%$ & $5.4 \%$ & $0.0 \%$ \\
\hline Culture, entertainment and recreation & $5.5 \%$ & $5.7 \%$ & $0.2 \%$ \\
\hline Construction & $5.5 \%$ & $5.6 \%$ & $0.1 \%$ \\
\hline Trade & $5.6 \%$ & $5.6 \%$ & $0.0 \%$ \\
\hline Professional and scientific activity & $6.2 \%$ & $6.4 \%$ & $0.2 \%$ \\
\hline Mining and quarrying & $8.4 \%$ & $8.1 \%$ & $-0.3 \%$ \\
\hline Water supply, sewage and waste management & $8.5 \%$ & $8.5 \%$ & $0.0 \%$ \\
\hline Transport, warehousing & $9.0 \%$ & $9.2 \%$ & $0.2 \%$ \\
\hline
\end{tabular}

Note: ${ }^{*} \mathrm{Q}$ - quarter.

$p>\alpha(p=0.2132)$. The largest increase in the number of companies experiencing problems in a given sector was in accommodation and catering $(0.9 \%)$. In transport and warehousing, professional and scientific activities, and the culture of entertainment and recreation, problematic companies also increased, but were slightly smaller (0.2\%). Noteworthy are two industries where the share of companies with problems decreased - real estate services (the share of companies decreased by $0.8 \%$ ) and mining and quarrying (the share of companies decreased by $0.03 \%)$.

The Spearman's rank correlation analysis tests whether there were any relationships between the value of the due payments of companies in individual industries and the percentage share of companies with problems in the first and second quarter of 2020.
Correlation coefficients are not statistically significant $p>\alpha$ for both the first and second quarters. Both relationships are positive, so as the due payments increase, the percentage of companies with problems in a given industry also increases. However, the dependence for the first quarter is higher and amounts to $37 \%$, and in the second quarter it decreases to $30 \%$.

\section{DISCUSSION}

The emergence of the COVID-19 pandemic has undoubtedly caused many perturbations, making it difficult to function in almost all areas of life and the economy. The introduction of more and more new restrictions concerning not only movement, but also business conduct, has led to an increase in the level of risk in terms of the possibility of survival and further operation of enterprises.

Table 3. Spearman's rank correlation coefficient between due payments in Q1 and Q2 and the share of companies with problems in Q1 and Q2*

\begin{tabular}{|c|c|c|}
\hline Detailed list & $\mathbf{R}$ & $\mathbf{p}$ \\
\hline Due payments value at the end of Q1 \& Share of troubled companies at the end of Q1 & 0.37 & 0.1287 \\
\hline Due payments value at the end of Q1 \& Share of troubled companies at the end of Q2 & 0.30 & 0.2302 \\
\hline
\end{tabular}

Note: $* \mathrm{Q}-$ quarter. 
During the pandemic, the Polish government introduced many facilities and assistance programs aimed at minimizing the negative effects that may appear as a result of the crisis caused by the pandemic. The main tool that was supposed to serve this purpose was the adoption of a package of legal acts related to the Anti-Crisis Shield. In the following months of the pandemic, efforts were made to create more and more versions of aid packages, in the hope that they would significantly help companies continue their operations.

Despite the fact that at present there are many government programs aimed at supporting economic entities, it cannot be denied that the presence of the pandemic has had a negative impact on the state of many of them. One can try to find reasons why the introduction of aid packages for enterprises, in a sense, did not fully bring about the expected results. It can be concluded that the support proposed by the government was insufficient and the payment problems of enterprises were too great to achieve the expected effect.

In today's reality, the majority of enterprises use trade credit as a tool for short-term financing of their activities. This tool has many undeniable advantages, but in times of worsening economic conditions, it can also increase the risk associated with the emergence of a wave of payment gridlocks. The closing of the economy resulted in a significant reduction in the revenues of some companies. This, in turn, negatively affected their ability to manage debt, which is largely driven by the amount of trade credit received.

\section{CONCLUSION}

The main purpose of this paper was to analyze the impact of the COVID-19 pandemic on the payment situation of Polish enterprises. Timely payment of liabilities is extremely important from the point of view of the stability of the functioning of enterprises in a given sector, as well as the entire economy. Therefore, based on the group of entities operating in various sectors of the economy, it was indicated how the status of arrears in payments of Polish enterprises changed in the first months of the pandemic. Considering how important it is for contractors to settle their liabilities in a timely manner, an attempt was also made to indicate possible potential consequences of this phenomenon for the future functioning of individual sectors and the entire economy.

The closing of the economy resulted in a significant reduction in the revenues of some companies, which, in turn, negatively affected their ability to regulate debt, largely due to the amount of trade credit received. The above statement is confirmed by the data collected and analyzed in this paper on the level of indebtedness of Polish enterprises at the initial stage of the pandemic. As the analysis showed, in enterprises from almost every industry, the value of due payments at the end of the second quarter of 2020 was higher than in the first quarter. It is difficult to draw specific conclusions, since the crisis caused by the COVID-19 pandemic has existed for a relatively short period of time, and, nevertheless it is evolving, revealing more and more aspects that it has affected. However, it cannot be denied that the impact of the pandemic on some enterprises is very negative, as evidenced by the growing share of enterprises with problems in general enterprises operating in a given industry.

The fact that the pandemic had such an impact on the state of arrears in the Polish enterprise sector shows that Polish companies are not sufficiently prepared for the emergence of perturbations on the market. Due to the pandemic and certain limitations in the functioning of some entities related to it, some of them could lose financial liquidity, as well as the ability to pay their liabilities on time. However, when analyzing the scale of the phenomenon of overdue payments on the Polish market, an increase in virtually all sectors of the economy can be noticed. Therefore, it can be concluded that there is a domino effect in this respect. Financial problems of one enterprise and the lack of payment for liabilities cause the emergence of liquidity problems in other entities that are its contractors. This state of affairs causes the phenomenon to spread to all sectors of the economy, which in turn, due to significant connections, may pose a risk of a wave of bankruptcy on the Polish market. 
More detailed and specific conclusions can be drawn when it is possible to accurately estimate the impact of a pandemic on the financial results of enterprises. At the moment, however, it can be noticed that the sharp limitation of the possibilities of conducting business activity by enterprises from various industries caused that these enterprises began to fail to cope with the payment of their liabilities. This, in turn, may pose a risk that they will not be able to continue their activities in the future, and therefore, there may be a risk of a wave of bankruptcies for companies most affected by the pandemic.

This study has the following limitations: The short analysis period, which arose from the relatively short presence of the pandemic in the country. Moreover, the results could be compared with data from other economies. In the future, it is planned to develop this study by significantly extending the analysis time span and making more detailed comparisons with other countries.

\section{AUTHOR CONTRIBUTIONS}

Conceptualization: Robert Dankiewicz, Bartłomiej Balawejder, Tomasz Tomczyk, Viktor Trynchuk. Data curation: Robert Dankiewicz, Bartłomiej Balawejder, Tomasz Tomczyk, Viktor Trynchuk. Formal analysis: Robert Dankiewicz, Bartłomiej Balawejder, Tomasz Tomczyk, Viktor Trynchuk. Investigation: Robert Dankiewicz, Bartłomiej Balawejder, Tomasz Tomczyk, Viktor Trynchuk. Methodology: Robert Dankiewicz, Bartłomiej Balawejder, Tomasz Tomczyk, Viktor Trynchuk. Project administration: Robert Dankiewicz, Bartłomiej Balawejder, Tomasz Tomczyk, Viktor Trynchuk. Supervision: Robert Dankiewicz, Bartłomiej Balawejder, Tomasz Tomczyk, Viktor Trynchuk. Validation: Robert Dankiewicz, Bartłomiej Balawejder, Tomasz Tomczyk, Viktor Trynchuk. Visualization: Robert Dankiewicz, Bartłomiej Balawejder, Tomasz Tomczyk, Viktor Trynchuk. Writing - original draft: Robert Dankiewicz, Bartłomiej Balawejder, Tomasz Tomczyk, Viktor Trynchuk.

Writing - review \& editing: Robert Dankiewicz, Bartłomiej Balawejder, Tomasz Tomczyk, Viktor Trynchuk.

\section{REFERENCES}

1. Agostino M., \& Trivieri F. (2019). Does Trade Credit Affect Technical Efficiency? Empirical Evidence from Italian Manufacturing SMEs. Journal of Small Business Management, 57(2), 576-592, https://doi.org/10.1111/ jsbm. 12410

2. Atradius (2018). Western Europe: an increase in past due B2B invoices. Atradius Payment Practices Barometer, 3. Retrieved from https://group.atradius.com/ publications/payment-practicesbarometer-western-europe-2018. html (accessed on March 2021).

3. Atradius (2019). Poland: higher insolvency levels Ahead. Atradius Payment Practices Barometer. Retrieved from https://group.atradius.com/publications/paymentpractices-barometer-poland-2019. html (accessed on March 2021)
4. Baranovsky, A., Tkachenko, N., Glonti, V., Levchenko, V., Bogatyrova, K., Beridze, Z., Belinskaja, L., \& Zelenitsa, I. (2020). NonPrice Criteria for the Evaluation of the Tender Offers in Public Procurement of Ukraine. International Journal of Financial Studies, 8(3), 44. https:// doi.org/https://doi.org/10.3390/ ijfs 8030044

5. Bărbuţă-Mişu, N. (2019). Analysis of factors influencing managerial decision to use trade credit in construction sector. Economic Research-Ekonomska Istraživanja, 31(1), 1903-1922. https://doi.org/10.1080/133167 7X.2018.1504690

6. Bhatti, A., Akram, H., Basit, H., Khan, A., Raza Naqvi, S., \& Bilal, M. (2020). E-commerce trends during COVID-19 Pandemic. International Journal of Future
Generation Communication and Networking, 13(2), 1449-1452.

7. Białowolski, P. (2011). Impact of Overdue Receivables on Economic Decisions of Enterprises. Prace i Materiały, Instytut Rozwoju Gospodarczego (SGH), 86(2), 67-79. Retrieved from https:// ideas.repec.org/a/wsd/irgpim/ v86y2011i2p67-79.html

8. Chod, J., Lyandres, E., \& Alex Yang, S. (2019). Trade Credit and Supplier Competition. Journal of Financial Economics, Elsevier, 131(2), 484-505. https://doi, org/10.1016/j.jfineco.2018.08.008

9. Ciżkowicz-Pękała M. (2017). Trade credit: a benefit to get, a "must" to give? Motives behind trade credit use in Poland. Financial Internet Quarterly “e-Finanse", 14(4), 55-56. https:// doi.org/10.1515/fiqf-2016-0035 
10. Connell W. (2014). Economic Impact of Late Payments

(European Economy - Economic Papers 2008-2015 531).

Directorate General Economic and Financial Affairs (DG ECFIN), European Commission.

11. Dankiewicz, R. (2020). Analysis of companies' bankruptcy in Poland as compared with the cost of protection under trade credit insurance. Journal of International Studies, 13(4), 197-212. https://doi. org/10.14254/2071-8330.2020/13$4 / 14$

12. Dankiewicz, R., Ostrowska-Dankiewicz, A., \& Bulut, C. (2020). The attitudes of entrepreneurs of the small and medium-sized enterprises sector in Poland to key business risks. Equilibrium. Quarterly Journal of Economics and Economic Policy, 15(3), 511536. https://doi.org/10.24136/ eq. 2020.023

13. Donthu, N., \& Gustafsson, A. (2020). Effects of COVID-19 on business and research. Journal of Business Research, 117, 284289. https://doi.org/10.1016/j. jbusres.2020.06.008

14. Eggers, F. (2020). Masters of disasters? Challenges and opportunities for SMEs in times of crisis. Journal of Business Research, 116, 199-208. https://doi. org/10.1016/j.jbusres.2020.05.025

15. Glonti, V., Trynchuk, V., Khovrak, I., Mokhonko, G., Shkrobot, M., \& Manvelidze, L. (2020). Socialization of Organization Sustainable Development Based on the Principles of Corporate Social Responsibility. Montenegrin Journal of Economics, 16(1), 169-182. https://doi. org/10.14254/1800-5845/2020.161.11

16. Grau, J., \& Reig, A. (2018). Trade credit and determinants of profitability in Europe. The case of the T agri-food industry. International Business Review, 27, 947-957, https://doi.org/10.1016/j. ibusrev.2018.02.005

17. Hopkins, P., \& Richmond, K. 2017. Scottish Enterprise, The economic impacts of late payment. Economic Commentary, 60-64. Retrieved from https://strathprints.strath. ac.uk/62013/1/FEC_41_3_2017_ HopkinsPRichmondK.pdf

18. Huang, L., Ying, Q., Yang, S., \& Hassan, H. (2019). Trade Credit Financing and Sustainable Growth of Firms: Empirical Evidence from China. Sustainability, 11(4), 1-20. https://doi.org/10.3390/ su11041032

19. Jurgilewicz, M., Zimon, G., \& Kmiotek, K. (2020). Financial Security Management in Central Units of Purchasing Groups. WSEAS Transactions on Business and Economics, 17, 910-920. https://doi. org/10.37394/23207.2020.17.89

20. Kaigorodova, G., Alyakina, D., Pyrkova, G., Mustafina, A., \& Trynchuk, V. (2018). Investment activity of insurers and the state economic growth. Montenegrin Journal of Economics, 14(4), 109-123. https://doi. org/10.14254/1800-5845/2018.144.8

21. Khovrak, I. (2013). Financing of innovative development: realities and prospects. Marketing and Management of Innovations, 1 , 229-235. Retrieved from https:// mmi.fem.sumdu.edu.ua/en/journals/2013/1/229-235

22. Khovrak, I. (2019). The impact of universities on sustainable regional development: Ukrainian context. Ideology and Politics Journal, 2(13), 15-65.

23. Khovrak, I., \& Petchenko, M. (2015). Estimating the level of financial safety in banking institutions. Actual Problems of Economics, 164(2), 347-354. Retrieved from http://dspace. univd.edu.ua/xmlui/handle/123456789/6851

24. Kumaraswamy, S., \& George, S. (2019). Trade credit management and firm profitability of Saudi manufacturing firms. Polish Journal of Management Studies, 20(1), 243-253. Retrieved from http://31.186.81.235:8080/api/ files/view/1085441.pdf

25. Levina, E., Pyrkova, G., Zakirova, C., Semikova, O., Nabiullina, K., Ishmuradova, I., \& Yako- vlev, S. (2015). Socio-economic systems strategic development managing. Journal of Sustainable Development, 8(6), 76-82. https:// doi.org/10.5539/jsd.v8n6p76

26. Lisowski, J. (2010). Specyfika gospodarki finansowej ubezpieczycieli kredytu kupieckiego w Polsce (p. 121). Poznań: Wydawnictwo Uniwersytetu Ekonomicznego w Poznaniu. (In Polish). Retrieved from https://books.google.ro/ books/about/Specyfika_gospodarki_finansowej_ubezpiec. html?id=9jFFtwAACAAJ\&redir $\mathrm{esc}=\mathrm{y}$

27. Lisowski, J., \& Chojan, A. (2020). The use of innovations in insurance: Case of trade credit insurance. Innovation in Financial Services: Balancing Public and Private Interests, 232-245. https:// doi.org/10.4324/9781003051664

28. Łyskawa, K., \& Janowicz-Lomott, M. (2014). Catastrophic risk in local government units: Search for optimal risk management. Contributions to Economics, 208, 115-129.

29. McGuinness, G., Hogan, T., \& Powell, R. (2018). European trade credit use and SME survival. Journal of Corporate Finance, 49, 81-103. https://doi.org/10.1016/j. jcorpfin.2017.12.005

30. Osieczko, K. (2019). Management of Cargo Transport at Airports. Modern Management Review, 24(26), 81-90. https://doi. org/10.7862/rz.2019.mmr.7

31. Ostrowska-Dankiewicz, A., \& Simionescu, M. (2020). Relationship between the Insurance Market and Macroeconomic Indicators in the EU Member States. Transformations in Business \& Economics, 19(3), 175-187. Retrieved from https://etalpykla. lituanistikadb.lt/object/LT-LDB0001:J.04 2020 1618838816958 /J.04 2020 1618838816958.pdf

32. Otto, W. H. (2018). Management of trade credit by small and medium-sized enterprises. Journal of Economic and Financial Sciences, 11(1), 1-8. https://doi.org/10.4102/ jef.v11i1.178 
33. Pantano, E., G. Pizzi, Scarpi D., \& Dennis C. (2020). Competing during a pandemic? Retailers' ups and downs during the COVID-19 outbreak. Journal of Business Research, 116, 209-213. https://doi. org/10.1016/j.jbusres.2020.05.036

34. Pasternak-Malicka, M. (2019). Szara strefa - definicje, przyczyny, szacunki. Polska perspektywa. Studia BAS, Biura Analiz Sejmowych Kancelarii Sejmu, Uwarunkowania prowadzenia działalności gospodarczej w Polsce, 2(58), 29-56. Retrieved from http://cejsh.icm. edu.pl/cejsh/element/bwmeta1. element.desklight-9987af6c-db2449b3-9828-837e66706611

35. Paul, S. Y., \& Boden, R. (2011). Size matters: the late payment problem, Journal of Small Business and Enterprise Development, 18(4), 732-747. https://doi. org/10.1108/14626001111179776

36. Petersen, M., \& Rajan, R. (1997). Trade credit: theories and evidence. Review of Financial Studies, 10, 661-691. https://doi. org/10.1093/rfs/10.3.661

37. Peura, H., Yang, S. A., \& Lai, G. (2017). Trade Credit in Competition: A Horizontal Benefit. Manufacturing \& Service Operations Management, 19(2), 263-289. https://doi.org/10.1287/ msom.2016.0608

38. Polinkevych, O., Khovrak, I., Trynchuk, V., Klapkiv, Y., \& Volynets, I. (2021). Business Risk Management in Times of Crises and Pandemics. Montenegrin Journal of Economics, 17(3), 117128.

39. Pyrkova, G., Kaigorodova, G., Mustafina, A., \& Alyakina, D. (2018). Financial risks: Methodological approaches and management methods. Journal of Social Sciences Research, Special Issue 5, 122-127. https://doi. org/10.32861/jssr.spi5.122.127

40. Ritter, T., \& Pedersen, C. (2020). Analyzing the impact of the coronavirus crisis on business models. Industrial Marketing Management, 88, 214-224. https:// doi.org/10.1016/j.indmarman.2020.05.014

41. Sołtysiak, M. (2014). Menedżerowie w procesie zarządzania ryzykiem. Modern Management Review - Quarterly, 19(21/2), 141-148. Retrieved from http:// yadda.icm.edu.pl/yadda/element/bwmeta1.element.ekonelement-000171343263

42. Tkachenko, N., Manvelidze, R., Khovrak, I., Glonti, V., \& Zelenitsa, I. (2020). Public procurement performance: criteria and indicators for Ukraine. At the International Business Information Management Association Conference (35st IBIMA), 11481157. Spain.

43. Trunina, I., Khovrak, I., \& Bilyk, M. (2020). Academic Entrepreneurship in Ukraine: Determinants of Development and Performance Indicators.
Proceedings of the 25th IEEE International Conference on Problems of Automated Electric Drive. Theory and Practice, PAEP, 9240891.

44. Van Horen, N. (2004). Trade Credit as a Competitiveness Tool; Evidence from Developing Countries (MPRA Paper 2792) (pp. 1-25). Retrieved from https:// papers.ssrn.com/sol3/papers. cfm?abstract_id $=562410$

45. Wilson, N. (2008). An Investigation into Payment Trends and Behaviour in the UK: 19972007. Leeds: CMRC Centre, Leeds University Business School.

46. Yazdinejad, E., \& Jokar, H. (2019). Discovering determinants of trade credit demand: Evidence from top managers insight. Cogent Economics \& Finance, 7, 1-15. https://doi.org/10.1080/23322039. 2019.1650611

47. Zimon, G., Ostrowska-Dankiewicz, A., Dankiewicz, R., Baranovska, V., \& Zelenitsa, I. (2019). Trade policy in the aspect of trade credit in group purchasing. Financial and Credit Activity: Problems of Theory and Practice, 1(28), 139-148.

48. Zimon, G. (2020). Issues of financial liquidity of small and medium-sized trading companies: a case study from Poland. Entrepreneurship and Sustainability Issues, 8(1), 363 372. https://doi.org/10.9770/ jesi.2020.8.1(25) 